Nur Ulina W Sebayang et.al Drum vermicomposting household scale as an additional source of income for farmers during the Covid-19 pandemic in Sidomulyo Village, Stabat District Langkat Regency, North Sumatra

\title{
Drum vermicomposting household scale as an additional source of income for farmers during the Covid-19 Pandemic in Sidomulyo Village, Stabat District Langkat Regency, North Sumatra
}

\author{
Nur Ulina Warnisyah Sebayang ${ }^{1 *}$, Hafnes Wahyuni ${ }^{1}$, Antonio Marro Sipayung ${ }^{1}$, \\ Sawitania C. Dwi U. Situmorang ${ }^{2}$ dan Khairunnisa ${ }^{3}$ \\ ${ }^{1}$ Program Studi Agroteknologi, Fakultas Pertanian, Universitas Sumatera Utara \\ ${ }^{2}$ Program Studi Agribisnis, Fakultas Pertanian, Universitas Sumatera Utara \\ ${ }^{3}$ Program Studi Manajemen Sumber Daya Perairan, Fakultas Pertanian, Universitas Sumatera \\ Utara \\ *Email: nurulinawarnisyah@usu.ac.id
}

\begin{abstract}
A large amount of livestock waste, rotten fruit and vegetable waste and there is a tofu factory that produces tofu dregs around farmer's house at Sidomulyo Village, Stabat District which can be used as an innovation for farmers during the Covid-19 pandemic. The limited activities of farmers in Sidomulyo Village make it difficult for farmers to work in the field because they are worried about the spread of Covid-19 and they try to follow the government's advice to continue to do social distancing and also physical distancing. This has an impact on the income and activities for farmers who daily have to be outside the home to carry out farming activities. To get additional sources of income and positive new activities, especially during the Covid-19 pandemic, this service was carried out by utilizing livestock waste and tofu waste in the environment around Sidomulyo Village by utilizing earthworms in drums to be processed into vermicompost which can be used self (household scale) as well as being developed and marketed for the cultivation of plants such as ornamental plants or horticulture plants.
\end{abstract}

Keyword: drum, vermicomposting, earthworm

\begin{abstract}
Abstrak
Banyaknya hasil limbah kotoran ternak, limbah buah dan sayuran busuk serta terdapat pabrik tahu yang menghasilkan ampas tahu di lingkungan sekitar rumah petani di Desa Sidomulyo Kecamatan Stabat ternyata dapat dijadikan inovasi baru bagi para petani pada masa pandemic covid-19. Terbatasnya aktivitas petani di Kelurahan Sidomulyo Kecamatan Stabat membuat para petani kesulitan dalam bekerja di lapangan karena khawatir akan penyebaran Covid-19 dan mereka mengikuti anjuran pemerintah untuk tetap melakukan sosial distancing dan juga physycal distancing. Hal ini berdampak terhadap penghasilan dan kegiatan petani yang sehari-hari harus berada di luar rumah untuk melakukan aktivitas bertani. Untuk mendapatkan sumber pendapatan tambahan serta kegiatan baru yang positif khususnya di masa pandemi Covid-19, kegiatan ini dilakulan dengan memanfaatkan limbah ternak serta limbah tahu yang ada di lingkungan sekitar Desa Sidomulyo dengan memanfaatkan cacing tanah dalam drum untuk diolah menjadi vermikompos yang dapat dimanfaatkan sendiri (skala rumah tangga) maupun dikembangkan dan dipasarkan untuk budidaya tanaman seperti tanaman hias, pangan maupun hortikultura.
\end{abstract}

Kata Kunci: drum, vermicomposting, cacing

\section{PENDAHULUAN}

Sejak WHO menetapkan COVID-19 sebagai pandemi pada 11 Maret 2020 yang lalu, seluruh negara (termasuk Indonesia dan tentunya Provinsi Sumatera Utara) telah menerapkan berbagai upaya pencegahan. Hal tersebut dilakukan dengan himbauan social distancing atau physical distancing, Pelaksanaan Perilaku Hidup Bersih dan Sehat (PHBS), serta melakukan pembatasan kegiatan- 
Nur Ulina W Sebayang et.al Drum vermicomposting household scale as an additional source of income for farmers during the Covid-19 pandemic in Sidomulyo Village, Stabat District Langkat Regency, North Sumatra

kegiatan sosial, adat, budaya, dan agama yang melibatkan banyak orang. Penyebaran Corona Virus Disease (Covid-19) di Provinsi Sumatera Utara sudah mencapai tahap mengkhawatirkan.

Jumlah kasus Covid-19 terus meningkat dari waktu ke waktu. Penerapan pembatasan dalam aktivitas sehari-hari memberikan dampak negatif pada kegiatan sektor pertanian di Kelurahan Sidomulyo Kecamatan Stabat Kabupaten Langkat, salah satunya terbatasnya ruang gerak para petani dalam beraktivitas dan bekerja yang berdampak pada menurunnya pendapatan ekonomi untuk memenuhi kebutuhan sehari-hari.

Menurut data penduduk di Kelurahan Sidomulyo Kecamatan Stabat Kabupaten Langkat, terdapat 6463 jiwa penduduk dan 729 diantaranya berprofesi sebagai petani. Disamping itu, para petani di Kelurahan Sidomulyo Kecamatan Stabat Kabupaten Langkat juga memiliki ternak ayam, itik, kambing dan sapi. Menurut Sebayang (2018), hasil sensus populasi ternak besar maupun ternak kecil tahun 2018 di Kelurahan Sidomulyo yaitu sapi (215 ekor), domba (347 ekor), kambing (330 ekor), ayam (1.500 ekor), dan itik (700 ekor).

Banyaknya hasil limbah kotoran ternak besar maupun ternak kecil yang tidak dimanfaatkan oleh petani dapat dijadikan inovasi untuk sumber pendapatan tambahan bagi para petani di Kelurahan Sidomulyo Kec.Stabat Kab. Langkat. Salah satunya adalah dengan melakukan pengomposan dari hasil limbah rumah tangga yang dipadukan dengan limbah kotoran ternak. Namun, ditengah situasi pandemik covid-19 yang masih mencekam, sangat sulit bagi petani bila harus melakukan proses pengomposan dalam skala besar di lapangan, belum lagi para petani juga harus mengikuti dan mentaati peraturan pemerintah untuk tetap membatasi aktivitas di luar rumah dan melakukan jaga jarak.

Dari hasil estimasi dan data di atas, maka tercetus inovasi dan ide untuk mengajak para petani di Kelurahan Sidomulyo Kecamatan Stabat Kabupaten Langkat untuk melakukan pengomposan skala rumah tangga dalam drum. Untuk mempermudah dan mempercepat proses pengomposan dapat memanfaatkan cacing tanah Pontoscolex corethrurus. Cacing ini biasanya disebut dengan cacing sampah atau cacing kompos yang dapat ditemukan dibawah tumpukan kayu atau tumpukans sampah rumah tangga. Secara morfologi cacing Pontoscolex corethrurus memiliki bentuk yang sedikit pipih dan berwarna merah kecoklatan dan berkilau keunguan. Cacing ini juga mudah hidup pada kotoran ternak seperti sapi.

Oleh sebab itu, tim pengabdian masyarakat ingin mengajak para petani melakukan proses vermikomposting skala rumah tangga yang nantinya akan dilaksanakan di rumah para petani di Kelurahan Sidomulyo Kecamatan Stabat Kabupaten Langkat. Kompos yang dihasilkan selanjutnya disebut sebagai "drum vermikompos" yang dapat dimanfaatkan sebagai pupuk organik penambah unsur hara pada pertanaman bunga hias di pekarangan rumah dan menjadikan produk baru yang dapat dipasarkan dan dijadikan sumber pendapatan tambahan di tengah pandemik Covid-19.

\section{METODE PELAKSANAAN}

Metode pendekatan yang akan dilakukan dalam pelaksanaan program pengabdian adalah melalui survei potensi/permasalahan di Kelurahan Sidomulyo Kecamatan Stabat Kabupaten Langkat, Sumatera Utara. Kemudian dilanjutkan dengan Focus Group Discussion (FGD).

Pelatihan bimbingan teknis pembuatan vermikompos, aksi/kegiatan dan pendampingan dan melakukan sosialisasi program melalui penyuluhan dan diskusi dengan masyarakat langsung di Kelurahan Sidomulyo Kecamatan Stabat Kabupaten Langkat. Sosialisasi meliputi bimbingan teknis pengomposan dengan memanfaatkan cacing tanah (vermikomposting), pengetahuan tentang manfaat vermikompos dan pembuatan produk "Drum Vermikompos".

Secara spesifik kegiatan dan tahapan PKM Dosen Wajib Mengabdi Tahun 2020 dapat digambarkan sebagai berikut : 
Nur Ulina W Sebayang et.al Drum vermicomposting household scale as an additional source of income for farmers during the Covid-19 pandemic in Sidomulyo Village, Stabat District Langkat Regency, North Sumatra

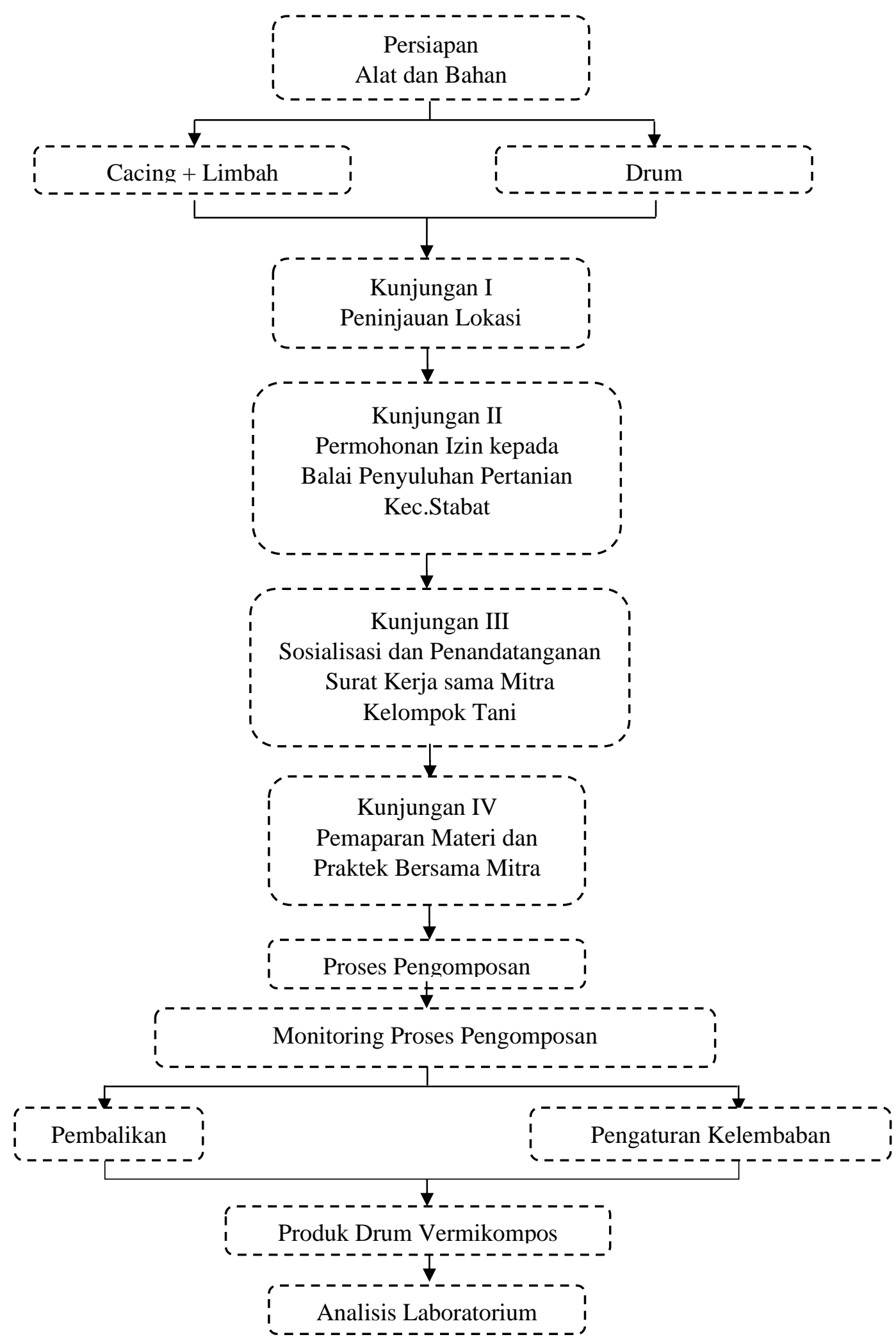

Gambar 2.1. Tahapan Pelaksanaan dan Gambaran IPTEK Kegiatan PKM 


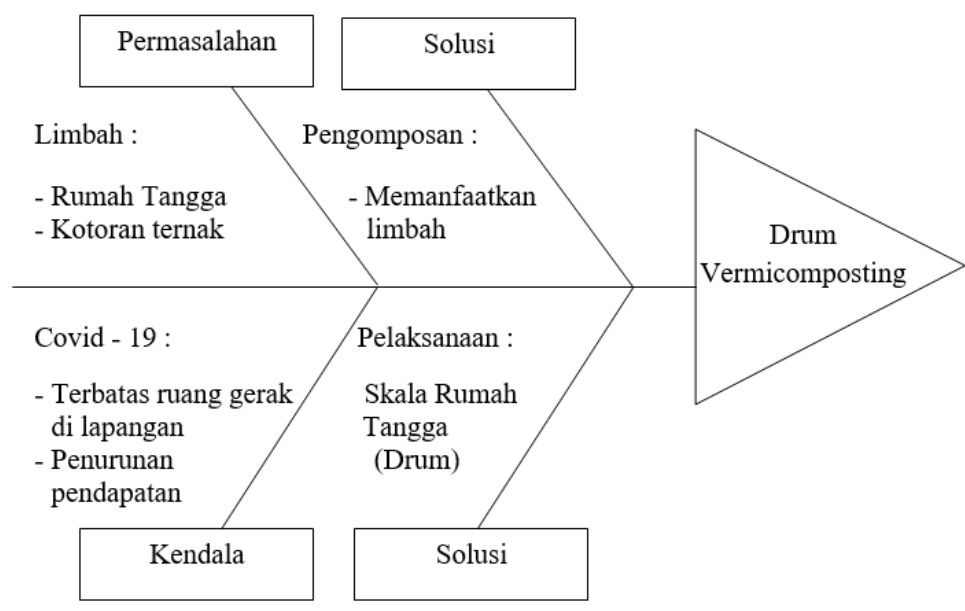

Gambar 2.2. Fishbone Diagram Kegiatan PKM Dosen Mengabdi Tahun 2020

\subsection{TAHAP PERSIAPAN ALAT DAN BAHAN}

Dalam tahap ini, dosen selaku pengusul kegiatan mempersiapkan segala dokumen dan kelengkapan berkas serta persiapan bahan baku (limbah kotoran ternak dan cacing kompos) yang dibutuhkan selama kegiatan pengabdian berlangsung. Berkas dan bahan baku yang telah tersedia disimpan terlebih dahulu oleh pengusul hingga saat serah terima alat dilakukan.

\subsection{TAHAP KUNJUNGAN}

Tahap kunjungan dibagi menjadi empat kali yaitu Kunjungan I (peninjauan lokasi), Kunjungan II (permohonan izin kepada badan pemerintahan setempat yakni Balai Penyuluhan Pertanian Kecamatan Stabat), Kunjungan III (sosialisasi kepada mitra kelompok tani yang dilakukan untuk menjelaskan latar belakang, tujuan, jangka waktu, dan mekanisme pelaksanaan kegiatan pengabdian ini untuk menghindari terjadinya missed communication diantara pengusul dengan mitra peserta pengabdian serta penandatanganan surat kerjasamamitra yang dibutuhkan), dan kunjungan IV (kegiatan pengabdian yaitu pemaparan materi serta praktek pengomposan drum vermikompos secara langsung bersama para petani).

\subsection{TAHAP PENGOMPOSAN}

Tahap pengomposan dilakukan dengan mencampur limbah kotoran ternak maupun limbah rumah tangga dengan cacing kompos di dalam drum/ember. Pada tahap awal pengomposan atau dekomposisi intensif berlangsung, dihasilkan suhu yang cukup tinggi dalam waktu yang relatif pendek dan bahan 329rotoco yang mudah terdekomposisi akan diubah menjadi senyawa lain. Pada tahap pematangan utama dan pasca pematangan, bahan yang sukar akan terdekomposisi akan terurai dan membentuk ikatan kompleks lempung-humus.

\subsection{TAHAP MONITORING}

Monitoring pengomposan dilakukan dalam bentuk pembalikan bahan-bahan kompos serta pengaturan kelembaban kompos agar kompos dapat terdekomposisi dengan baik dan menjaga kelembaban juga diperlukan untuk keberlangsungan hidup cacing.

\subsection{TAHAP PENANGANAN PASCA PEMATANGAN KOMPOS}

Setelah kompos matang dengan ciri ciri tidak berbau; remah; berwarna kehitaman; mengandung hara yang tersedia bagi tanaman; dan kemampuan mengikat air tinggi, maka 
Nur Ulina W Sebayang et.al Drum vermicomposting household scale as an additional source of income for farmers during the Covid-19 pandemic in Sidomulyo Village, Stabat District Langkat Regency, North Sumatra

dilakukan tahapan analisis kandungan unsur hara di laboratorium yang meliputi : $\mathrm{pH}, \mathrm{C}$ Organik (\%), N Total (\%), $\mathrm{P}_{2} \mathrm{O}_{5}(\%), \mathrm{K}_{2} \mathrm{O}(\%)$.

\section{HASIL DAN PEMBAHASAN}

Program pengabdian Dosen Wajib Mengabdi Tahun 2020 telah selesai dilaksanakan di Kelurahan Sidomulyo, Kecamatan Stabat, Kabupaten Langkat. Kegiatan dilakukan dengan melakukan empat kali kunjungan seperti yang telah dijelaskan pada metode pelaksanaan. Kegiatan pengomposan dihadiri oleh 10 orang anggota kelompok tani yang terdiri dari petani dewasa serta petani muda. Kegiatan pengabdian dilakukan dengan dua tahap yaitu pemaparan materi mengenai drum vermikompos yang dijelaskan oleh ketua tim pengabdian (Nur Ulina Warnisyah Sebayang, SP., M.Agr) dan praktek pembuatan drum vermikompos yang dibantu oleh empat anggota tim pengabdian (Hafnes Wahyuni, SP., MP, Antonio M. Sipayung, SP., M.Agr, Sawitania C.D.U Situmorang, SP, Msi dan Khairunnisa Spi, Msi). Kegiatan ini juga dilakukan dengan menerapkan protokol Covid-19 yaitu menggunakan masker, mencuci tangan dengan sabun atau menggunakan hand sanitizer serta menjaga jarak.
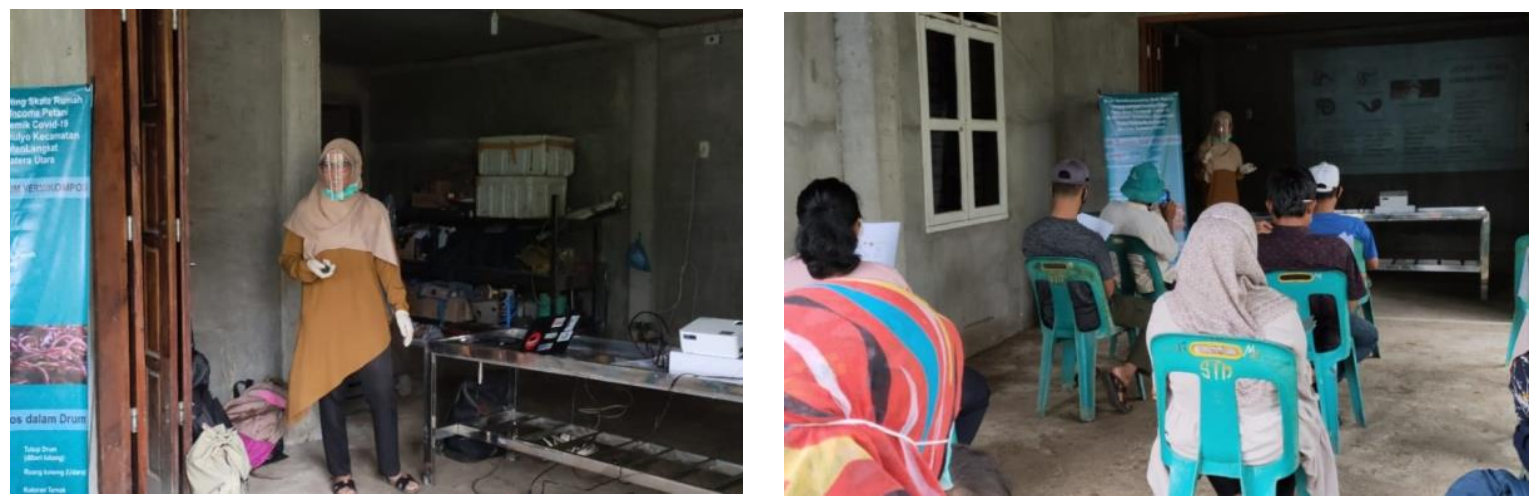

Gambar 3.1. Pemaparan materi oleh ketua tim pengabdian dosen wajib mengabdi 2020.
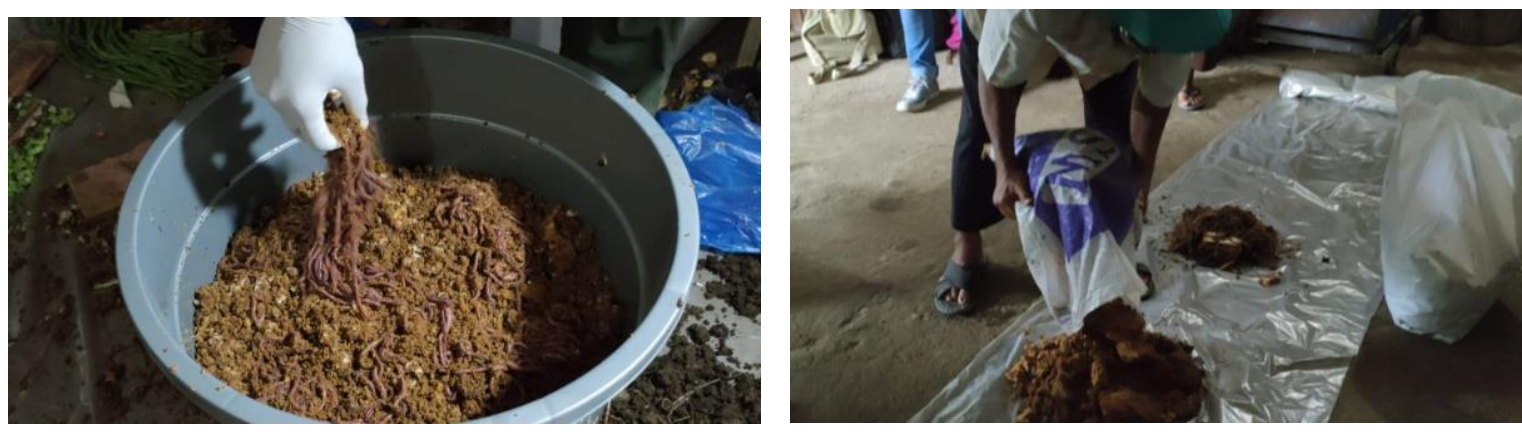

Gambar 3.2. Bahan-bahan yang digunakan dalam pembuatan drum vermikompos.
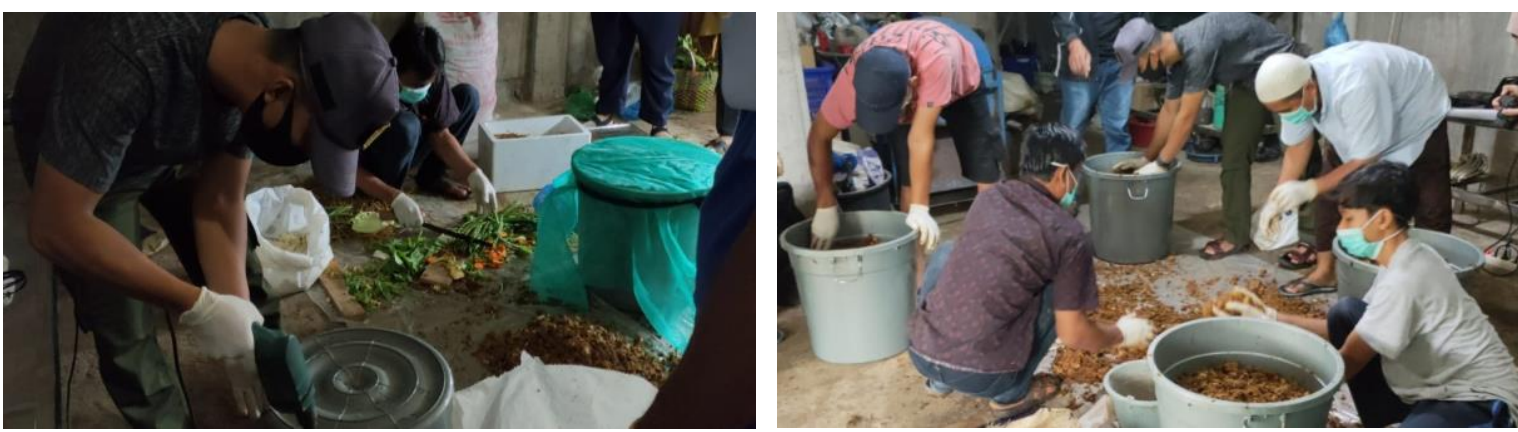
Nur Ulina W Sebayang et.al Drum vermicomposting household scale as an additional source of income for farmers during the Covid-19 pandemic in Sidomulyo Village, Stabat District Langkat Regency, North Sumatra

Gambar 3.3. Proses praktek pembuatan drum vermikompos

Pelubangan drum dengan bor untuk lubang pembuangan air dan pencacahan bahan baku (kiri), Proses pencampuran bahan-bahan (kanan).
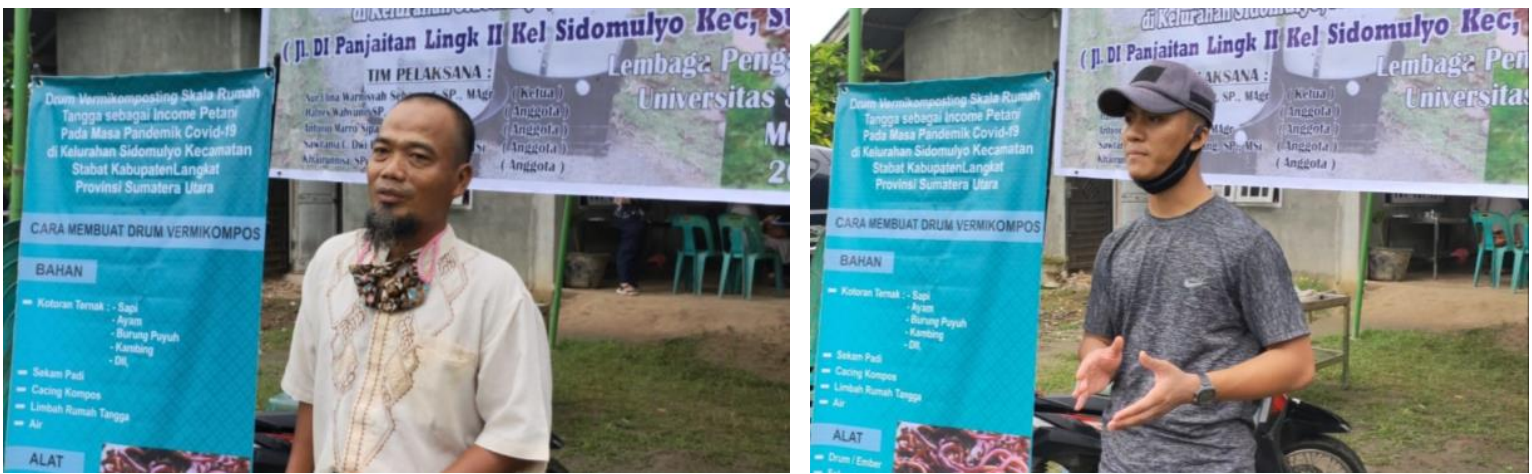

Gambar 3.4. Kesan dan pesan terhadap kegiatan pengabdian yang dilakukan tim USU ketua kelompok tani (kiri) dan petani muda (kanan).

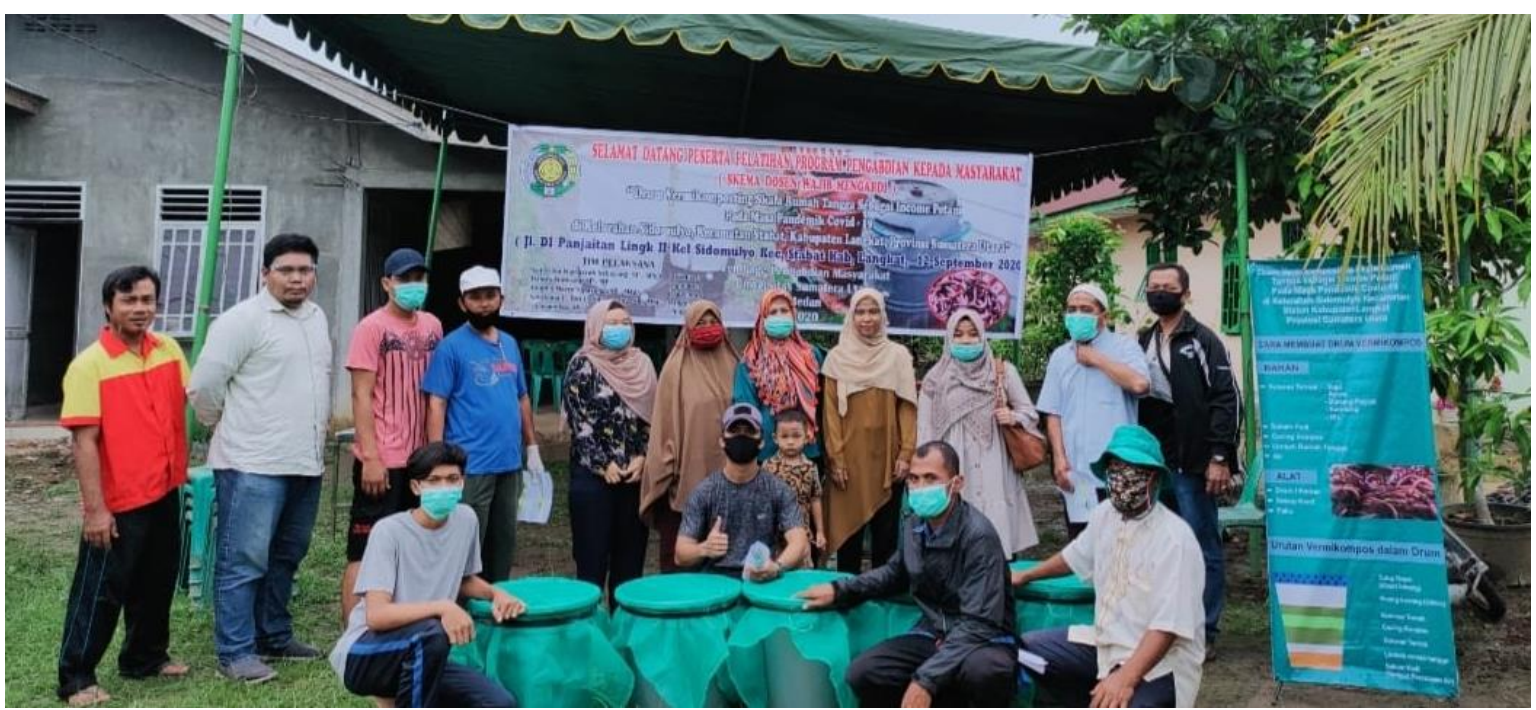

Gambar 3.5. Tim pengabdian dosen wajib mengabdi USU tahun 2020 bersama mitra.

Setelah praktek pembuatan vermikompos selesai dilakukan, masing-masing petani diberikan drum vermicomposting untuk dibawa ke rumah masing-masing. Selama proses pengomposan, tim pengabdian tetap melakukan monitoring by phone untuk mengetahui perkembangan proses pengomposan. Setelah kompos matang dengan ciri-ciri tidak berbau; remah; berwarna kehitaman, maka beberapa sampel diambil untuk dibawa ke laboratorium agar dianalisis kandungan hara nya.
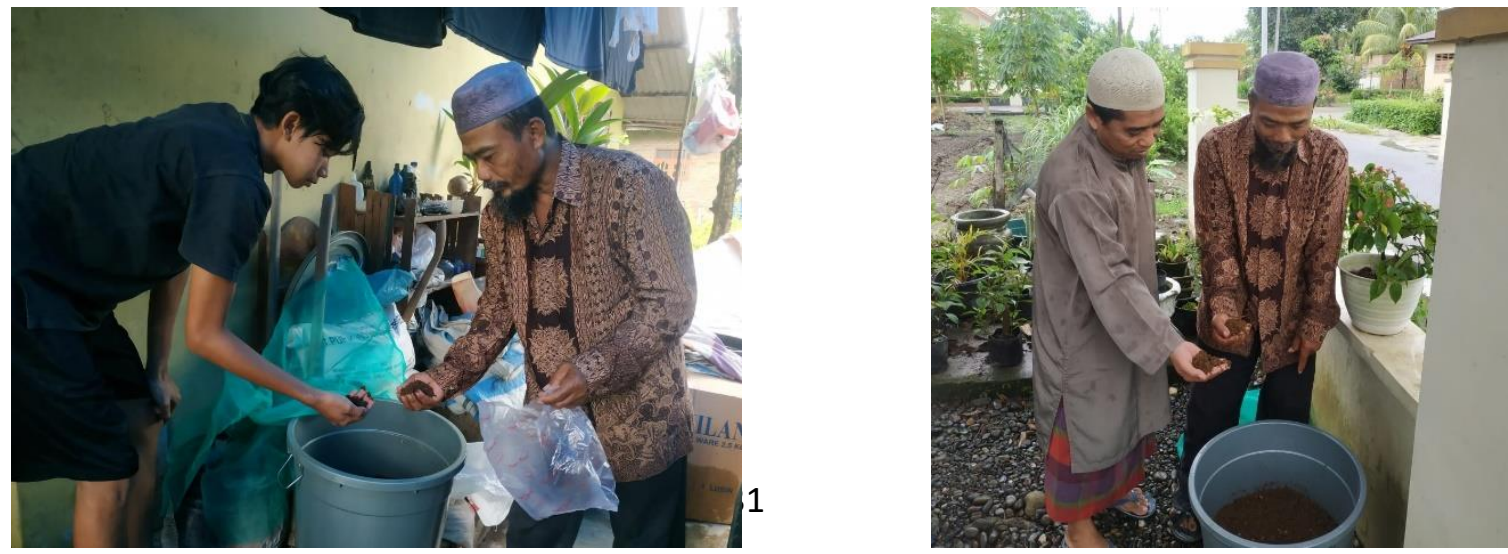
Gambar 3.6. Proses pengecekan terhadap kematangan kompos.
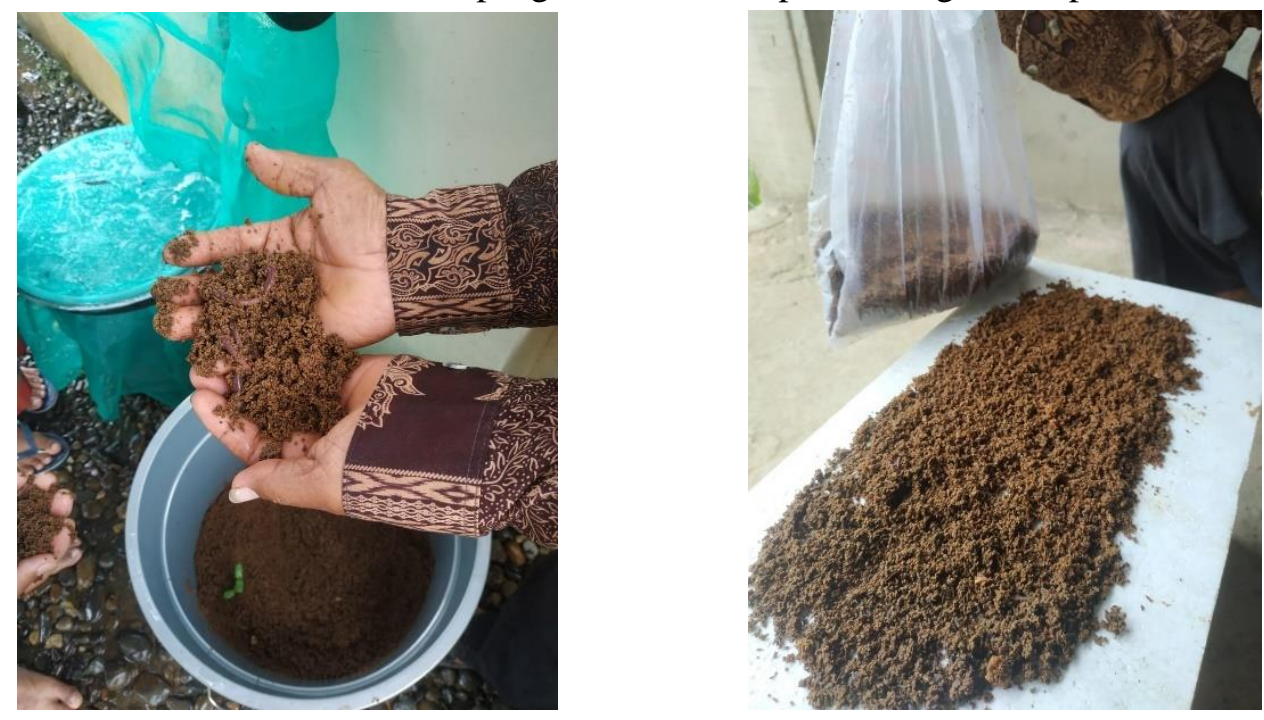

Gambar 3.7. Pengambilan sampel kompos untuk di analisis di laboratorium.

\begin{tabular}{|c|l|c|c|c|}
\hline No. & \multicolumn{1}{|c|}{ Parameter } & Nilai & Metode & Batas SNI \\
\hline 1. & C-Organik $(\%)$ & 10,01 & Gravimetri & $9,8-32$ \\
\hline 2. & N-Total $(\%)$ & 1,47 & Kjehdal & Min 0,4 \\
\hline 3. & $\mathrm{~K}_{2} \mathrm{O}(\%)$ & 0,55 & AAS & Min 0,20 \\
\hline 4. & $\mathrm{P}_{2} \mathrm{O}_{5}(\%)$ & 3,49 & Spectrofotometri & Min 0,10 \\
\hline 5. & $\mathrm{pH}$ & 8,94 & Elektrometri & $6,8-7,49$ \\
\hline 6. & Kadar Air (\%) & 74,25 & Drying Oven & $0-50$ \\
\hline 7. & Rasio C/N & 6,80 & & $10-20$ \\
\hline
\end{tabular}

*Dianalisis di Laboratorium BPTP Medan.

Tabel 3.1. Hasil analisis vermikompos.

Berdasarkan analisis laboratorium (Tabel 3.1) terlihat bahwa parameter kimia C-Organik, NTotal, $\mathrm{P}_{2} \mathrm{O}_{5}$ dan $\mathrm{K}_{2} \mathrm{O}$ yang diukur berada pada kisaran yang ditetapkan BSN (2004), sedangkan $\mathrm{pH}$ lebih alkalis dari batas SNI kompos, kadar air lebih tinggi dari 50\%, sementara Rasio C/N lebih rendah. Meskipun kadar air kompos masih tinggi, tetapi mudah diatasi dengan mengangin anginkan beberapa waktu sebelum dikemas. N-Total, $\mathrm{P}_{2} \mathrm{O}_{5}$ dan $\mathrm{K}_{2} \mathrm{O}$ merupakan unsur mineral makro yang keberadaannya sangat ditentukan oleh bahan baku kompos. Kandungan unsur hara makro dalam vermikompos tergolong cukup tinggi yaitu $\mathrm{N}(1,47 \%), \mathrm{P}_{2} \mathrm{O}_{5}(3,49 \%)$ dan $\mathrm{K}_{2} \mathrm{O}(0,55 \%)$. Unsur utama yang menyebabkan kompos mudah menyatu dengan tanah adalah apabila $\mathrm{C} / \mathrm{N}$ rasionya berada pada kisaran $10-20 \%$. Surtinah (2013) menyatakan $\mathrm{C} / \mathrm{N}$ rasio yang terkandung didalam kompos menggambarkan tingkat kematangan dari kompos tersebut, semakin tinggi nilai $\mathrm{C} / \mathrm{N}$ rasio didalam kompos menunjukkan kompos belum terurai secara sempurna atau belum matang. Menurut Hanafiah (2005) kompos yang memiliki nilai $\mathrm{C} / \mathrm{N}$ kurang dari 20 berarti unsur-unsur hara yang terikat pada limbah organik tersebut telah mengalami proses penguraian dan mineralisasi sehingga menjadi tersedia dan dapat diserap oleh akar tanaman. 
Nur Ulina W Sebayang et.al Drum vermicomposting household scale as an additional source of income for farmers during the Covid-19 pandemic in Sidomulyo Village, Stabat District Langkat Regency, North Sumatra

Menurut Wahyono dan Sahwan (2010) nilai agronomis kompos meliputi (i) $\mathrm{pH}$ dari kompos harus netral, (ii) konsentrasi $\mathrm{N}_{2} \mathrm{P}_{2} \mathrm{O}_{5}$ dan $\mathrm{K}_{2} \mathrm{O}$. Konsentrasi unsur humus utama dalam kompos $\mathrm{N}$, $\mathrm{P}_{2} \mathrm{O}_{5}$ dan $\mathrm{K}_{2} \mathrm{O}$ dari masing-masing tipe kompos tergantung dari penggunaannya, dan (iii) kemampuan pengikat air (SNI 19-7030- 2004). Kemampuan kompos dalam mengikat air untuk menetapkan dalam mengevaluasi kualitas kompos. Namun menurut literatur lain Jaun et al (1959) dalam Setyorini et al (2010) bahwa salah satu ciri kompos telah matang adalah dalam keadaan alkalis. Vermikompos yang dihasilkan dari kegiatan pengabdian ini memiliki nilai $\mathrm{pH}$ yang dikategorikan kedalam alkalis. Hal ini kemungkinan dapat terjadi karena bahan baku pembuatan kompos yang terdiri dari beberapa limbah rumah tangga, limbah peternakan dan limbah pabrik (ampas tahu) yang bersifat alkalis.

\section{KESIMPULAN}

Berdasarkan kegiatan pengabdian yang telah dilakukan di Kelurahan Sidomulyo, Kecamatan Stabat, Kabupaten Langkat, petani sangat antusias dalam mengembangkan drum vermicomposting dan ingin mempelajari lebih lanjut sebagai usaha. Kegiatan ini juga dirasakan para petani sangat bermanfaat saat pandemik Covid-19 sedang melanda. Hasil sifat kimia vermikompos yang telah dianalisis di laboratorium sudah baik sesuai SNI Kompos (19-7030-2004) terutama dalam unsur hara makro (N, P dan K).

\section{UCAPAN TERIMAKASIH}

Penulis mengucapkan terima kasih kepada Lembaga Penelitian dan Pengabdian Masyarakat Universitas Sumatera Utara yang telah mendanai kegiatan Pengabdian Dosen Wajib Mengabdi tahun 2020, kepada seluruh tim pengabdian yang telah bekerja dengan baik, kepada Balai Penyuluhan Pertanian Kecamatan Stabat yang telah menjembatani tim pengabdian kepada kelompok tani Songgomulyo di Kelurahan Sidomulyo Kecamatan Stabat Kabupaten Langkat, serta kepada adikadik mahasiswa yang telah turut berpartisipasi dalam kegiatan ini.

\section{DAFTAR PUSTAKA}

BSN (Badan Standarisasi Nasional). 2004. Spesifikasi Kompos dari Sampah Organik Domestik. SNI 19-7030-2004.

Hanafiah, K. A. 2005. Dasar-dasar Ilmu Tanah. Jakarta: Raja Grafindo Persada.

Surtinah. 2013. Pengujian Kandungan Unsur Hara dalam Kompos yang Berasal dari Serasah Tanaman Jagung Manis (Zea mays saccharata). Jurnal Ilmiah Pertanian 11(1): 16-26.

Setyorini, D., R. Saraswati dan E. K. Anwar. 2010. Kompos. JRI 6(3). BPPT. Jakarta. 